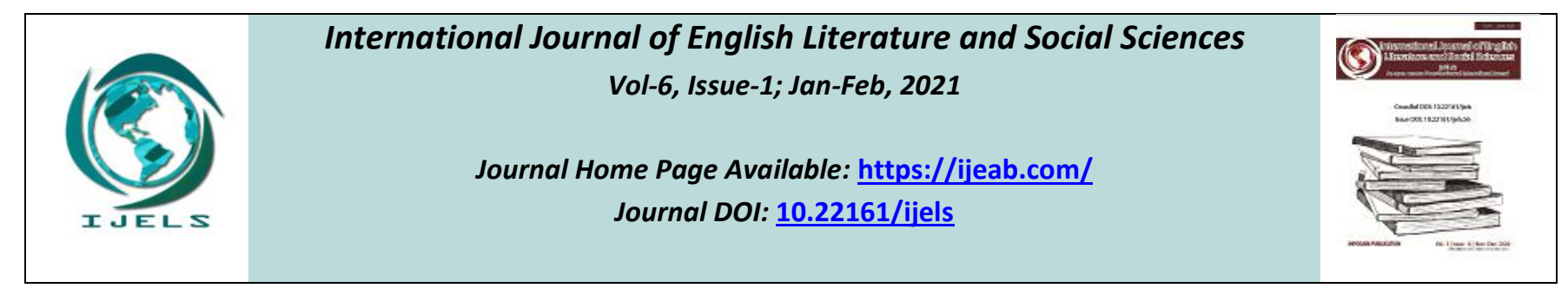

\title{
Challenges Facing Community Involvement in Ensuring Quality Education in Public Secondary Schools in Meru District, Arusha Region-Tanzania
}

\author{
Haika Lauwo, Demetria Gerold Mkulu
}

Department of Educational Foundation, St. Augustine University of Tanzania, Mwanza, Tanzania

Received: 07 Nov 2020; Received in revised form: 28 Dec 2020; Accepted: 10 Jan 2021; Available online: 14 Jan 2021

C2021 The Author(s). Published by Infogain Publication. This is an open access article under the CC BY license

(https://creativecommons.org/licenses/by/4.0/).

\begin{abstract}
The purpose of this paper was to examine the challenges facing community involvement in ensuring quality education in public secondary schools in Meru District. The study employed mixed research approach and convergent parallel design. The study used a sample size of 89 participants which were solicited using both probability and none probability sampling techniques. Quantitative and qualitative data were collected through questionnaires and interviews respectively. Descriptive statistics used to analyze the quantitative data through SPSS version 20 and Microsoft excel Packages, the data were presented through frequency, percentage, charts, and tables. Qualitative data were recorded using field note book, and audio recorder device and were analyzed using thematic analysis. The instrument for quantitative was validated using content validity while Cronbach coefficient of 0.7 was obtained. Qualitative instrument was validated using peer review. The findings revealed that, ignorance, poor school leadership, poverty, political interference, poor beliefs and customs and lack of communication between the school and the community are the major challenges facing communities in participating in schools. Finally, the study recommends that for improving and inhibiting the highlighted challenges, deliberate strategies should be laid down and the government should sensitize educational partnership so as to improve the community participation in schools.
\end{abstract}

Keywords - Community involvement. Quality Education, public secondary schools. Academic performance.

\section{INTRODUCTION AND BACKGROUND TO THE STUDY}

This paper examined the challenges facing community involvement in ensuring quality education in public secondary schools in Meru District Arusha Tanzania.

The role of community participation in ensuring quality education in school is highly important in any educational institution. Among the community duties were to make sure that nutrition, shelter, transport, clothes, social care, giving extra time doing their homework, improvising teaching and learning materials. Epstein (2012) argued that community participation is important in the provision of quality education services to the learners. Henderson and Mapp (2002) suggested that community involvement in school activities have a greater impact on academic achievement than more general forms of involvement. Additionally, Borgonovi and Montt (2012) identified two categorizes of community involvement; academically-oriented home based involvement and non-academic based activities. Specifically, academically oriented activities includes; paying school fees, buying books and assisting learners in homework. In addition, the non- academic home based activities include; provision of nutrition, parental care, guidance and counselling, 
communicating with teachers, and transport facilities. Based on this understanding, both academic and non-academic community found to be the factors to accelerate the chances of quality education in secondary education in most countries. Epstein (2009) adds that, both academic and non-academic activities oriented community involvement in school provides children with parenting services and simplifies communication between schools and communities for the purpose of ensuring quality education.

Historically community involvement has long history since ancient time in which parents and guardians provided informal education to young generations. More specifically, the historical of community involvement in schools began in most African countries in the $19^{\text {th }}$ century when agency of education was voluntarily involved in control and management of funding, provision and management of education. The notable communities involved in schools activities included; Church Missionary Society (CMS), the Wesleyan Methodist Church Mission (WMCM), and the Roman Catholic Mission (RCM). The aforementioned societies worked in ensuring provision of quality education in primary and secondary education (Obomanu, 2010). Community involvement means that parents, guardians and other members get into directly or indirectly contributing funds or non-financial materials for enhancing quality education for their children (Clinton \& Hattie, 2013). In addition, Hornby and Rafaele (2011) insist that community involvement is the significant element in the provision of quality education of which it can be achieved through home based parental involvement. The notable home-based activities like listening to child and helps children to complete their homework, contributing in building school infrastructure, attending parent meetings and workshops in schools. The study surveyed work of literature from the global scope to specific area. Strategies, achievement and factors, hinders achievement of community involvement in ensuring quality education have been surveyed in various countries including; Indonesia, Nigeria, and Tanzania.

In Indonesia, community participation has been regulated in article 4 of Law Number 20 Year 2003. It states that the community is entitled to participate in the stages of planning, implementing, monitoring, and evaluating educational program. The community has an obligation to provide resources for the implementation of education too. Based on such facts, the role of community involvement in improving the quality of education in public secondary schools is in terms of giving advice, giving supports to educational quality, controlling school activities; and as a mediator of the government (Kusumaningrum et al., 2017). On the same note, the school committee as the representative of community performs activities such as making recommendations on school expenditures, teacher qualifications, and school facilities. In addition, the school committee is expected to act as a mediator between the school and the community, and promote the community, especially parental involvement in the school (Pradhan et al., 2011)

In Nigeria, national policy of education stresses the necessity of community involvement in the running of secondary schools. The community participation is not limited to facility construction only but extends to the provision of schools for the education of her members. In Nigeria, community establishes schools for the education of her members and also actively participates in the funding of such schools. Funding depicts the provision of economic resources (funds) which invariably means money for a project, businesses or any other private or public institutions. More specifically, Igbinedion (2006) described funding as the application of money, men and material to the efforts aimed at the achievement of goals and objectives of the community involvement in provision of quality education for learners in secondary school. More importantly, Okpala (2003) Nigerian Government creates community involvement in schools through parents' teachers association (PTA) as a strategy for funding of quality education. In addition, Ugwu (2000) stated that the community which was the source of the Parents Teachers Association with enormous functions such as fund raising, maintenance of school discipline and participatory of efforts of the community to building schools, so as to afford their children the benefits of educating. .Moreover, Tobeho (2000) maintained that in Nigeria community participates in ensuring quality education in secondary schools by funding schools activities through fees and other channels.

In Tanzania, the efforts of ensuring community involvement in secondary schools accompanied by several implementation of several policies including; The Education and Training policy, and Education Sector Development Programme policy (URT, 2010). Just as, for the first time in the year 1964, Tanzania introduced a five years development plan in which the country came up with objectives which the country required to meet and strive to expand secondary education of which each policy insists on community participation (Molel, 2015). In line with the argument given by the United republic of Tanzania in pursuant of aforementioned policies, community have been given priorities in several aspect including, making decision, providing land for building school, constructing buildings, and fees contributions as the

\section{ISSN: 2456-7620}


cost sharing. The policy reforms on key policy documents such as Tanzania development vision 2025 the national strategy for growth and reduction of poverty (NSGRP), The Education and Training Policy of 1995, program ESDP (2001), and Millennium Development Goals (MDGs) prioritized the community participation in education as a strategy of improving its quality. Despite of government praiseworthy efforts, yet the community involvement in school academic-related activities in Meru district such as learning and teaching process, decision making process and curriculum planning process have not met as it has been expected by the surroundings communities. In fact in Meru district communities are rarely involved in non-academicrelated activities such as contribution of funds. Therefore it is from this regards that the study was eager to investigate contribution of community involvement in ensuring quality education in public secondary schools in Meru District, in Arusha region.

\subsection{Statement of the Problem}

In relation to the background described, there was no clear policy which ensured community involvement in public secondary school in academic-related activities (Muthoni, 2015). Based on this standpoint, community members have been aloof in working together with the government. The role of community for a long time has remained to be that of nonacademic related including; provision of finances for infrastructure developments, attending annual meetings and provision of security and healthcare to their children. The notable efforts that government of Tanzania has tried to ensure in the provision of quality education to its people includes the providing teachers, learning resources and facilities. Despite all government efforts, quality education has not been achieved as expected in secondary schools in Meru district. As noted by Muthoni (2015) the government did not state clearly who is responsible for ensuring community role in academic-related activities in schools. In reality, the community should be treated as an integral part of the school and it's roles seen more as complementary rather than supplementary. Community involvement has the potential of increasing access to education and retention of learners for ensuring quality education. It was from this regards, the researcher examined the impacts of community involvement in ensuring quality education in public secondary school in Meru district.

\subsection{Significance of the Study}

The study is to challenge the community member to know the potentials of their involvement in academic-related to their children academic performance. It is also to show how community participation helps in improving decision making that in turns supports the implementation of the agreed courses of action. Furthermore, community feels duty-bound to guide the students in their school work as well as taking charge of discipline of their children. Furthermore, the study is to provide an insight to the local community authorities about their potentialities in ensuring quality education to their children in public secondary schools.

The study was challenged teachers to collaborate with parents in improving learner's performance in their exams through parent teacher association. The study is to provide knowledge and an insight to policy makers on developing new policies that would aid to involve community's participation in the provision of quality education. Moreover the study is to be of benefit to students on their education in the sense that they are to acquire knowledge about the potentiality of community involvement in ensuring quality education in public secondary schools. Finally, the study is to help the researcher to gain more knowledge and create a new ground in the potentiality of community involvement in academic-related activities in public secondary schools.

\section{LITERATURE REVIEW}

\subsection{Challenges Facing Communities in Enhancing Quality Education}

Kambuga conducted a study in Tanzania (2013) about the role of community participation in on-going construction of ward based schools. The findings show that community members were reluctant to contribute through physical participation on the basis that funds disbursed by the government were enough to facilitate construction of classrooms, teachers' houses and toilets. This notion was imparted to people's mind by opposition parties which were campaigning to the community not to contribute or participate in school construction. The argument was verified on $26^{\text {th }}$ June, 2013 by former minister of MOEVT, Dr. Shukuru Kawambwa who said "some politicians who wanted to destroy the good will of the government and ruling party in ensuring that all pupils who passed standard seven examinations should have a chance for secondary education in the nearest place by mobilizing people not to continually contribute to the construction of classrooms and teachers' houses. However, he requested the government and security agencies to take strong measures against any person regardless of his/ her status in society who will continue mobilizing people not to participate in development initiatives. 
Onsomu and Mujidi (2011) confirm that in majority of Africa countries, teachers appear not to accommodate community involvement to become more productive. In view of their studies, Fullon and Watson (2013) provided that for school administration and teachers to understand the schoolcommunity relationship they are to address the nature of the relationship that exists, how parents and teachers can work together for school improvement and how teachers can be integrated into the community. In line with this understanding, Guillaume (2011) opines that fewer instructions for communities become a challenge to accommodate and attract community to get more involved in school activities. The most disheartening issues includes; inadequate meeting times for communities, less effective communication mechanisms and none home visits by teachers and school leaders. More importantly, Muthoni (2015) asserted that in most cases schools leaders or administrators did not attempt to establish a partnership with the community in the surroundings believing that community members are irrelevant to the schooling process. On the same note, school leaders or administrators believed that most of community members are illiterate or had low educational background at that time , anything to do with school was intimidating to them . In support of the view, Naidoo and Anton (2013) in their studies provided that in most cases the communities are not given chance in doing the business of schooling, create site-based decision making that involves communities and recreate a school structure that is less bureaucratic, less impersonal and less budget-driven and in general overcoming barriers to parent involvement in the broad context of needed systemic changes. The above mentioned and discussed challenges slow down the commendable efforts for the government and other educational stakeholders in achieving high degree of schoolcommunity partnership for the realization of quality education in public secondary schools.

Singh, Mbokodi and Msila (2004) provided that low income challenges effectiveness of community involvement in school related activities like helping their children school work and giving them counseling and guidance. They continuous to maintain that such challenge results into poor academic and behaviors among children as they receive no any support from community. Prew conducted a study in (2012) which found that community shared community responsibility depending on economic levels. In his view, middle-class member of the community are much more likely to see themselves as having shared responsibility for the schooling process. In reverse the lower-class member of the community appear to turn over responsibility for education to the school as they believed that they are less concerned. Additionally, Oppenheim (2008) argued that community, especially those are in the workingclass and lower-class are not always an educational resource, and they are reluctant in performing school activities such as manual work and intellectual work. Moreover, Lareau (2006) speak the same idea that working class and lower class community do not usually tend to be involved in the children's schooling activities . Based on argument given by Oppenheim in his study, the situation less involvement of community in school activities created constraints in the school- community relationship resulting in poor school development. The argument of Prew and Oppenheim converge behind the idea that well-endowed community with income are sensitive in involvement in school activities while lower income earners are less collaborative in involving in school activities. Conversely, Comer (2009) in his views points out that those minority communities may lack knowledge about school protocol and may feel inadequate or unwelcome due to differences of income, education or ethnicity compared to the school personnel. To support the idea Adams and Christenson (2000) emphasizes that if negative perception between community and school organization is developed, trust and collaboration will subsequently be lowered among community to be involved in school development. In line with the argument, Hornsby (2011) maintained that low socioeconomic status affects effective involvement of members in the community to provide effective quality education because they are less involved and informed in school activities.

The study conducted by Donoghue (2014) supported that, the situation in which community and school organization develops negative perception towards poor communities seem to pose a greater barrier for less affluent families than more affluent. For decades, teachers have been perceiving community as unimportant factors to be considered for school progress. However, this perception has led to the development of unwelcoming atmosphere for community in schools, low level of democracy and ineffective communication between schools and parents. Ibrahim (2012) in his study conducted in Indonesia found that communities were even disappointed since the school staff did not let them know about several cases occurred which involved their children.

\section{METHODOLOGY}

\subsection{Research Approach}

The study employed mixed research approach in collecting, analysing data and interpreting the results. Creswell (2012) defined mixed research approach as the procedures for

\section{ISSN: 2456-7620}


collecting, analysing and interpreting data using quantitative and qualitative method in a single study. The study combined both quantitative and qualitative approach in order to provide better understanding of the research problem understudy.

\subsection{Research Design}

The study employed convergent parallel research design. Creswell (2012, p 540) defined convergent parallel research design as a simultaneous plan of collecting both quantitative and qualitative together and analyse it differently. It helps the researcher to compares the results for better understanding of the problem under the study. The study adopted convergent parallel research design in manner that quantitative data were collected through questionnaires closed and open ended questions and analysed in descriptive statistics. Qualitative and quantitative data ware used in separate and the researcher related the results for the interpretations.

\subsection{Target Population}

The targeted population of the study was 210 people including all students, all teachers, all parents, all heads of schools and District Educational Officer in the study area. Mikaye (2012) defines population as the group of elements such as individuals, objects, or items from which sample was taken. The study specifically selected four schools in Meru district council to draw the population of the study. This study involved all students, teachers, parents, school board members and district education officer to create a sample size.

The study employed two sampling techniques including, stratified sampling technique, and purposive sampling technique. Creswell (2012) defined stratified sampling as the techniques in which researchers divide the population regarding in some specific characteristics and then using simple random sampling to sample from each subgroup of the population such as ethnical group. However, the study employed stratified sampling technique in sampling teachers and students to meet population characteristics such as gender, ethnicity, religion, age, and educational level. The study also employed purposive sampling to select members of school board, heads of selected schools, and District secondary educational officer in the study area. Patton (2015) defined purposive sampling technique as the deliberately selecting sample units that conform to some predetermined criteria in a study population. The study choose purposive sampling techniques in sampling key informants including, members of school boards, HoS, DEO, in the study for the reason they have specific information required by the researcher. Also, five parents were included in the sample due to potentiality of their existence.

\subsection{Sample Size}

Herman (2016) argued that sample size is the number of participants' elements that have been selected from the target population. The sample size of the study was 89 respondents from four public secondary schools in the study area using Yamane (1967) formula as proposed by Singh and Masuku (2014): $\mathrm{n}=\frac{\mathrm{N}}{1+\mathrm{N}(\mathrm{e})^{2}}$

Whereby, $\mathrm{n}=$ Sample size; $\mathrm{N}=$ Total population; $\mathrm{e}=$ Level of precision. From population of five hundred, a sample of eighty nine participants was obtained from the total population to provide the data. Sample computation was done as shown:

a) Sample for teachers:

$\mathrm{n}=\frac{N}{1+\mathrm{N}(\mathrm{e})^{2}}$, therefore

$\mathrm{N}=72, e=0.1$, Level of confidence $=99$.

$\mathrm{n}=\frac{72}{1+72(0.1)^{2}}$

$\mathrm{n}=\frac{72}{1+72(0.01)}$

$\mathrm{n}=\frac{72}{1.72}$

$\mathrm{n}=41.8 \approx 42$

b) Sample for students.

$\mathrm{n}=\frac{N}{1+\mathrm{N}(\mathrm{e})^{2}}$, therefore

$\mathrm{n}=\frac{60}{1+60(0.1)^{2}}$

$\mathrm{n}=\frac{60}{1+60(0.01)}$

$\mathrm{n}=\frac{60}{1.6}$

$\mathrm{n}=37$

Total sample size was 37 students, 42 Teachers, 5 Parents, 2 School board members, 4 Heads of Schools and District Educational Officer. Therefore total samples were 89 respondents as summarized in table 3.1. 
Table 3. Sample Matrix ( $n=89)$

\begin{tabular}{lclcl}
\hline Parameter & T/ Population & S/Size & Percentage & Sampling Techniques \\
\hline DEO & 1 & 1 & 1.1 & Purposive \\
HoS & 29 & 4 & 4.1 & Purposive \\
BOM & 29 & 2 & 2.0 & Purposive \\
Parents & 19 & 5 & 5.1 & Purposive/snowball \\
Teachers & 72 & 42 & 47.1 & stratified/simple random \\
Students & 60 & 37 & 41.0 & stratified/simple random \\
\hline Total & 210 & 89 & 100.0 & \\
\hline
\end{tabular}

Source: Researchers' design (2020).

The study employed questionnaire and interview in collecting the data. Kombo (2006) defined questionnaire that, is the research instrument that gathers data over a large sample. The study used questionnaire methods in collection data from students and teachers for reason that, it helps the researcher to collect information easily from big sample size in a short time. Interview also was used. Kothari (2014) defined interviews as the questions asked orally and was categorized into various forms such as structured, semi-structured and unstructured interviews between an interviewer and interviewee. Therefore, in the study the researcher used unstructured interview to explore first-hand information from the respondents through probing deeper into respondents' experiences, feelings, opinions, and suggestions.

Ngussa (2017) describe validity as the way of justifying the appropriateness of instrument utilized by the researcher in the study. The study was ensured content validity through determining the relevance of the content used in the questionnaires and interview schedule. The researcher examined each questionnaire and interview schedules to provide feedback whether the instruments measure what they are supposed to measure. Chege (2015) defined reliability as the extent to which results are constant overtime and collect representation of the total population. On the same note, The study measured reliability through entered the data from pilot study into the SPSS programme to computer the Cronbach Alpha coefficient $(\alpha)$ the data from pilot study were collected into entered into SPSS programme and a Cronbach Alpha coefficient $(\alpha)$ of 0.7 was obtained, this value indicated that the instruments were reliability and acceptable.

Furthermore, the study employed both qualitative and quantitative approaches in recording and analysing the data from study area. Patton (2015) defined data analysis as the process of cleaning, transforming and modelling data to discover useful information for decision making. On the first hand the data collected through questionnaire and analysed using descriptive statistics with the help of Statistical Package for Social Science (SPSS) version 20 computer program, the data were presented in graphs, charts, tables, frequencies, and percentages. Nevertheless, qualitative data from interviews were recorded using field note book and pen, the interviews were recorded using smartphones and were transcribed to make sense of meaning and analysed through thematic analysis. Themes were generated, corded and summarized and described in details in chapter four to make sense of the findings.

Additionally, the researcher considered ethics used in education research. Kumar (2014) described ethics of research as concerned with the appropriateness of the researcher's behaviour in relation to the subjects of the research or those who are affected by it. The study ensured ethical before and during data collection process. Before data collection process the researcher obtained a research permit from the Vice Chancellor of St. Augustine University of Tanzania to introduce her to the authority in the study area. Additionally, the researcher asked permission from regional administrative secretaries in Arusha region, Meru district administrative secretary and district educational officer for collecting data from the sampled public secondary schools. Finally, the researcher consulted the head of selected public secondary schools for appointment of visiting their schools in order to conduct an interview for members of the board, parents and provision of questionnaires for teachers and students to be filled. During data collection process ethical issues like informed consents, right to privacy, honesty with professional colleague and protection from harm. This study ensured 
ethical practices by making respondents aware of the purpose of the study, protect respondents by providing and interviewee were informed that they would be assigned pseudo names such as Silver, Gold, Diamond, Gypsum, Graphite, Tanzanite, Copper, Magnesium and Dynamite. The permission letters was addressed to the DEO and heads of institution to ask for their acceptance to conduct research in their administrative areas.

\section{FINDINGS AND DISCUSSION}

\subsection{Respondents Response Rate of Return}

The researcher administered questionnaires to the 42 teachers, 37 students, and 10 were interviewed and giving total number of 79. All questionnaires were returned indicating a response rate of 100 percent. Additionally, all 10 key informants were interviewed using in-depth interview guide, who also returned a response rate of 100 percent and all interviewees were available for analysis and discussion.

\subsection{Challenges Facing Communities in Ensuring Quality Education}

In this objective the researcher intended to identify the challenges communities face in ensuring quality education in Meru District. Both teachers and students were provided with questionnaires to fill in. The results showed that there are major barriers which hinder the community not to participate to its fullest rates these constraints include ignorance, poor leadership, poor beliefs and customs, poverty, political interference and lack of communication between the school and the community. The findings were in the figure below.

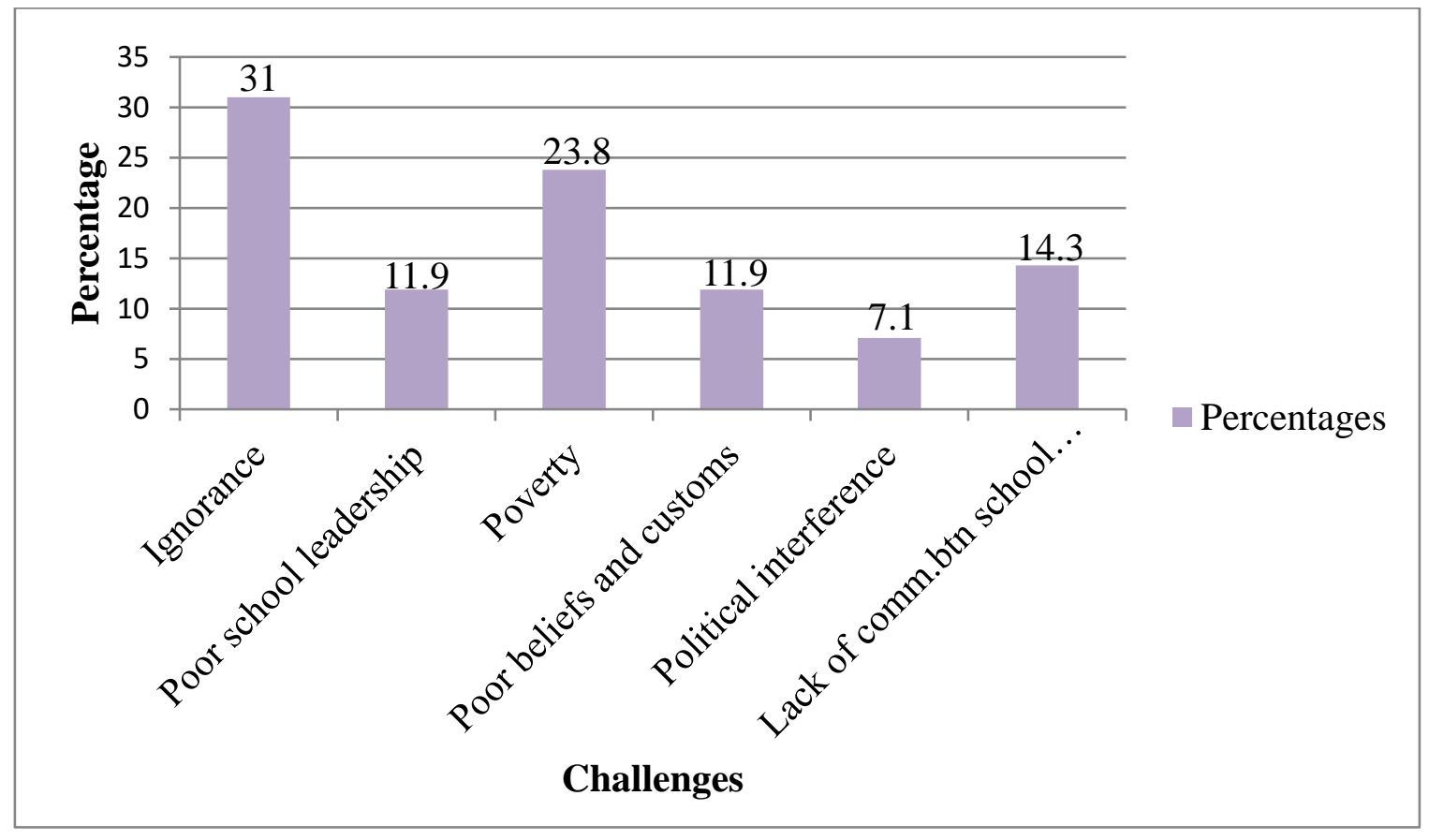

Fig.4: Challenges Communities Face in School Involvement ( $n=42)$

Source: Field data (2020).

Figure 4.3 indicates that 31 percent of the teachers said that community involvement in school is hampered by ignorance. Most of the parents in the study area are living in the limb of ignorance. Community member do not know the value of them to participate in their children, they just take student to school and leave them to teachers, leaving teachers only with the duty of handling students issues could not be productive, it requires inclusive involvement the parents, teachers and the government. One of the interviewee captured that:
Community participation in school is affected by ignorance of the parent himself or herself, most parents are not aware with their contribution when they involve in school. The interviewee added that ignorance of the parent is what makes a student to perform poorly because the parent does not even worry about their student progress (Interviwee, I 03.08.2020). 
The quotation above discerned that parents' level of education has positive impact with the students learning achievement, so to limit this there should be deliberate effort to educate parents on the importance of involving in education.

On the question of poor school leadership, a number of 11.9 percent of the respondents agreed that, community involvement in academic related activities is eroded by the nature of the school leader whether democratic or authoritarian. Leadership approach enables to open doors for the outsiders to instill their ideas in school development. In our locations we have a school leader who doesn't need cooperation with the community; he/she rejects their ideas as a result parents withdraws from participating. To support this, the following observation exemplified:

In our area parents do not involve directly to their children education because of poor school leadership which does not support community participation, the school leader is not transparency, do not value their ideas and undervalued them, al, these attributes to poor parent involvement and hence poor student performance (Interviewee, 10.08.2020).

The statement above indicates that there is poor leadership in schools which does not facilitate community involvement in school as the result affecting the provision of quality education in public schools.

Another challenge faces community involvement is school is poverty, about 23.8 percent of the respondent articulated that, most parents live in poverty, and they are not sure of their meal and cannot afford the school expenses. Schools are located distant from the household members where it requires paying fare to reach school. This argument correlated with Mbokodi and Msila (2004) who asserted that low income challenges effectiveness of community involvement in school related activities like helping their children to do their school works and giving them guidance and counseling.

Figure 4.3 indicates that poor beliefs and customs was a barrier towards community involvement in academic related activities. A total number of 11.9 percent of the teachers said that communities does not involve in school because of the belief and customs. For example, from the experience of the area of the study women very seldom participate into their children, they believe that it's the role of the man to know how a child go to school, what to wear and if a female student gets problem they conclude that her mother knows. This statement is exemplified by the following quotation:
In our society members of the community lacks commitment to school because they think that it's not their role, they show this role when a child is still too young at the lower class, but soon after the adolescent and if a boy is circumcised he can support himself, this situation leaves many boys dropping out of school, becoming small business persons and hence, poor academic achievement (Gypsum, 07.08.2020).

The findings indicate that some beliefs, customs and culture have negative impact over children education; hence they facilitate poor academic performance among students.

On the issue of political interference, 7.1 percent of the teachers agreed that it is one of the challenges hinders community from not involving to the fullest degree. Politicians have adverse impact in quality education because they decelerate the community morale of participating, the have tendency of discouraging parents from contributing to the school development. When these happens, they greatly affect the performance of the students and hence failure to attain the quality of education. Kambuga (2013) revealed that, community members were reluctant to contribute through physical participation on the bases that the funds disbursed by the government were enough to facilitate construction of classroom, teachers' houses and toilets.

Figure 4.3 also indicates that 14.3 percent of the respondents said that community involvement was eroded by the lack of communication between school and the community. There is poor relationships between the school and the community at larger, the case which triggers communication breakdown. The miscommunication can be because of poor leaderships, parents' poor altitude towards schools, present social classes among the communities and the ignorance. To resolve these stumbling blocks it needs both parties to see that every part has value over the development of another parameter. To support this Muthoni (2015) contends that school leaders or an administrator does not establish a partnership with the community in the surroundings believing that community members are irrelevant to the schooling process. School leaders believe that community members are illiterate or had poor educational profiles, so to involve them in education matters is like kidnapping them.

On the other hand, students were given questions to answer concerning the question of community involvement in academic related activities and the results were presented in table below:

\section{ISSN: 2456-7620}


Table 4. Challenges Hindering Community Involvement in School ( $n=37)$

\begin{tabular}{lcc}
\hline Parameter & Frequency & Percentage \\
\hline Ignorance & 11 & 29.7 \\
Poor school leadership & 5 & 13.5 \\
Poor beliefs and customs & 3 & 8.1 \\
Poverty & 9 & 24.3 \\
Political interference & 3 & 8.1 \\
Lack of communication between school and community & 6 & 16.2 \\
Total & $\mathbf{3 7}$ & $\mathbf{1 0 0 . 0}$ \\
\hline
\end{tabular}

Source: Field data (2020)

Table 4.9 indicates that 29.7 percent of the students who participated in the study said that ignorance is the major hindrance toward community participation in school. Most parents are non-educated, they are busy with their own staffs, they don't concern with students learning pretending that teachers are responsible with the caring of students. Many parents believe that their roles is just to send their children to school, the other issues are left to the teachers. For example, with the provision of fee free education, parents has left all the responsibility to the government, it very difficult to convince a parent to contribute fund for laying the building, paying food fees and paying other cost like medicatio costs.

On the issue of poor school leadership, 13.5 percent of the participants stipulated that it is a stumbling block towards community involvement in academic issues in public secondary school in the area. Most school administrators lack leadership skills which led them not to involve different stakeholders especially the community, they always judge communities as they are not responsible, they illiterate and has nothing to contribute in school development. School decisions are not inclusive in the sense community members are less considered, they led the school be ineffective. If there is poor relationship between the school and the community automatically leads to communication breakdown. Fullon and Watson (2013) argues that school administrators and teachers understand the school-community relationship they should have to address the nature of the relationship that exists, how parents and teachers can work together for school development and how teachers can integrate in the community.

Table 4.9 also indicated that 8.1 percent of the students said that poverty detracts community from participating in school activities. Poverty is the state of an individual not to afford the life expenses. The finding establishes that some parents in the area are facing this challenge which forces them not to involve in their children schooling; most of them are peasant and living slums, they lack the money to contribute to school, fail to buy students uniform, they are not the money to buy transport means for their children and they are able to put good learning environment at home like electricity installations, buy solar panel and so forth. Prew (2011) asserted that, community share community responsibility depending on the economic levels which cause social stratifications. One interviewee quotes that:

Poverty is a barrier because it takes lot of time to have money to contribute at school, it causes parents not to accommodate their children leaving them suffering from poor condition, and they lack uniforms, food, transport means or fare and meals accommodations (Magnesium, 05.08.2020).

The result suggests that, poverty is direct proportional to poor organization performance, poor parent involvement and limits a person not to meet his or her desires of life.

Another challenge face community participation in school is poor beliefs and customs, this view was supported by 24.3 percent of the respondents who participated in the study. In most African tradition, it is the father who is responsible with ensuring that children get to school, have every required regardless of the economic stability of the household leader, mother in the other coin, they are not responsible, even if they are good economically; these reasons causes many children to dropout from school, other engage in early pregnancy, other become business person and others becomes street children. Moreover, political interference, 8.1 percent of the students agreed that community involvement is detracted by political interference. This became very serious very recently after the 
introduction of fee free education programme and leaving the cost sharing approach which reprimanded parents to concern into their children education.

Lack of communication between parents and community was another challenges hindered parents not to participate in the academic related activities in Meru District. A total number of 16.2 percent of the respondents agreed with the allegations. Communication is sharing of ideas between people for the interest of reaching at a certain rational consensus. School leadership required to engage stakeholders of education in decision making concerning school achievement, valuing their ideas and respecting them. To support this, Guillaume (2011) argued that less instructions for communities become a challenge to accommodate and attract community to get more involved in school activities; mist of intimidating issues includes; inadequate meeting times for communities, less effective communication systems and non-home visit by teachers and school leaders.

\section{CONCLUSIONS AND RECOMMENDATION}

\section{Conclusion}

In objective two it was found that community participation is obstructed by many challenges like ignorance, poor school leadership, poverty and political interference. These challenges stems from the community, schools and the whole society. In objective two it was found that community participation is obstructed by many challenges like ignorance, poor school leadership, poverty and political interference. These challenges stems from the community, schools and the whole society.

\section{Recommendation}

There should be deliberate initiatives to promote community involvement in public secondary schools. The District education office should ensure that heads of schools are competent and have the adequate knowledge, skills and competencies on school leadership. Parents should support their children by ensuring that they have all the materials to support their learning. The government through school management should emphasize on Parent Teachers Association (PTA).

The current study focused on public secondary schools, similar study should be conducted in private secondary schools. Another study should be conducted on the impact of community involvement in achieving quality education in public secondary schools.

\section{REFERENCES}

[1] Adams, K.S., \& Christenson, S. L (2000). Trust and the FamilySchool Relationship: Examination of Parent-Teacher Differences in Elementary and Secondary Grades. Journal of School Psychology, 38 (5); 477-497.

[2] Borgonovi, F. \& Montt, G. (2012). Parental involvement in selected PISA countries and economic Education Working Paper. No. 73. Paris OECD Publishing.

[3] Chege, K.G. (2015). The variance of pupils' perception of different areas of guidance and counseling and their effects on pupils discipline in Soy constituency, Kenya. Greener Journal of Educational Research, 5(3), 50-56.

[4] Comer, J.P. (2009). School reaching out: Family school and community partnerships for student's success in children's education and urban society. New York. Thomas Hoffer Basic Books Publishers.

[5] Creswell, J.W. (2012). Educational Research planning, conducting, and evaluating Quantitative Research, (4 ${ }^{\text {th }}$ ed.). Boston, MA: Pearson Education Inc.

[6] Donoghue, K.L. (2014) Barriers to parental involvement in schools: Developing diverse programs to include unique demographics.

[7] Clinton, J, and Hattie, J. (2013). New Zealand students' perceptions of parental involvement in learning and schooling. Asia Pacific Journal of Education 33(3), 324-337.

[8] Epstein, J.L., Sanders, M. G., Sheldon, S. Simon, B. S., Salinas, K. C., Jansorn, N. R., \& Williams, K. J. (2009). School, family, and community partnerships: Your handbook for action. Thousand Oaks, CA: Corwin.

[9] Epstein, L.J., (2012). School, Family, and Community Partnerships: Your Handbook for Action. West Port: Greenwood Publishing Press Limited.

[10] Hornby, G. (2011). Parental involvement in childhood education: Building effective school-family partnerships. New York: Springer.

[11] Ibrahim, J.S. (2012). Accommodating parental participation in managing school. Journal of Education and Practice, 4(12)

[12] Kasumaningrum, D. E., Nurul, U., Teguh, T., \& Imam, G. (2017). "Community participation in improving educational quality". Advances in Economics Business and Management Research, 45(75), 39-47.

[13] Kombo, D.K., \& Tromp, D.L.A. (2006). Proposal and thesis writing (An introduction). Nairobi. Paulines Publications Africa.

[14] Kothari, C.R. (2014). Research methodology: Methods and techniques ( $3^{\text {rd }}$ ed.). New Delhi: New Age International Publishers.

[15] Mapp, K.L., \& Kuttiner, P.J. (2013). Partner in education: A dual capacity-building framework for family-school partnerships. Family Review, (43), 338-368.

[16] Muthoni, C.K. (2015). The impact of community involvement in the public secondary in schools management, (Master's thesis), Kenyatta University. Machakos, Kenya. 
[17] Ngussa, B.M. (2017). Assessment of Teachers Participation in Decision Making in Public Secondary School of Moshi Municipality, Tanzania. Journal of Research Innovation and Implication in Education 1(4), 13-24.

[18] Onsomu, N.E., \& Mujidi, J. (2011). Community schools in Kenya: A case study on community participation in funding and managing schools. International Institute for Educational Planning, UNESCO.

[19] Oppenheim, M. (2008). Critical place of community development in school transformation: The story of the Vaughn family center and Pacime urban Village. Canberra: AGPS Publishing Company Limited.

[20] Patton, M.Q. (2015). Qualitative research and evaluation methods (4 ${ }^{\text {th }}$ ed.). Thousand Oaks, CA: Sage.

[21] Pradhan, M. (2011). Improving education quality by enhancing community participation. New York: World Bank.

[22] Prew, M.S. (2012). Community involvement in school development: Modifying school improvement concepts to the needs of South African township schools. London: SAGE Publishers.

[23] Reece, C., Staudt, M., \& Ogle, A. (2013). Lessons learned from a neighborhood-based collaboration to increase parent engagement. School Community Journal, 23(2), 207-226.

[24] Robbins, C., \& Searby, L. (2013). Exploring parental involvement strategies utilized by middle school interdisciplinary teams. School Community Journal, 23(2), 113136.

[25] The United Republic of Tanzania, Vice President Office (2005). National Strategies for Growth and Reduction of Poverty, Dar es Salaam.

[26] Tusiime, H.M. (2012). The technology of research and grant proposal writing: A Precise step-by-step guide to proposal formulation. Saarbrucken. Lambert Academic Publishing.URL: 